\title{
NON-AGENDA
}

With the view of causing an increase to take place in the mass of national wealth, or with a view to increase of the means either of subsistence or enjoyment, without some special reason, the general rule is, that nothing ought to be done or attempted by government. The motto, or watchword of government, on these occasions, ought to be - Be quiet. . . Whatever measures, therefore, cannot be justified as exceptions to that rule, may be considered as non-agenda on the part of government.

\section{Policy Contradiction: Australia's Car Export Facilitation Scheme}

\author{
David Pearce
}

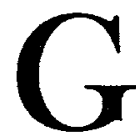

overnment intervention to support particular industries often has unintended and contradictory effects. Attempts to correct these effects with further intervention may lead to additional costs and further unintended effects. Australia's automotive industry provides an excellent example of this.

The recent export performance of the Australian automotive sector has been impressive. Exports have more than trebled since 1984, and in 1993 were worth about the same as exports of education services ( $\$ \$ 1.5$ billion). The exports are diverse - including vehicles such as the Mitsubishi Verada, engines and a wide variety of components - and mostly go to the US, Japan and New Zealand.

This boom in automotive exports has been widely reported and some commentators have seen it as proof of Australia's newly found international competitiveness in manufacturing. But rather than being a positive sign, the exports reveal the inherent contradictions in Australia's automotive industry policy. How can exports boom in an industry that is struggling with reductions in border protection? That is, how is it that an industry, which by its own admission cannot compete with overseas producers on the domestic market, manages to compete with those same producers on the international market.?

The short answer is simple. Just as Australia's automotive industry is protected or subsidised on the domestic market, many of its exports are subsidised on the international market. The subsidy takes place through an export facilitation scheme that has been operating in Australia since 1982. 


\section{The Contradiction}

Few Australian industries have received as much government support as the automotive industry. Almost since its inception the industry has been projected by a variety of schemes (sometimes changing annually) designed to protect the industry from a changing international environment. Protection steadily increased throughout the 1960s and exploded in the mid-1970s with the introduction of import quotas. Only comparatively recently, as the costs of protection have become unsustainable, has protection begun to decline.

One problem with all this import protection is that it created a bias against exporting. Imagine that the automotive industry has two types of production - for export markets and for the domestic market - that are roughly interchangeable. The actual combination of domestic and export production depends on the relative rewards from each type of production.

Without import tariffs on motor vehicles, both domestic production and exports receive the world price and will be equally attractive. If an import tariff is introduced, production for the domestic market receives the world price plus the rate of the tariff. For example, with a 30 per cent tariff, a car selling on the world market for $\$ 10,000$ could be sold on the domestic market for $\$ 13,000$ (excluding sales taxes and other on-road costs). Exports, however, can be sold only at the world price, $\$ 10,000$. Thus, production for the domestic market becomes relatively more attractive, earning 30 per cent more than production for export markets.

This is where export facilitation comes in. Export facilitation aims to correct the bias against exports created by the protection given to import-competing industries, by providing exporters with the same protection (in this case a 30 per cent subsidy) that producers supplying the domestic market receive. Although its details have varied since its introduction in 1982, the scheme essentially allows producers, in return for exports, to purchase imported vehicles free of duty: that is, the producer has to pay only $\$ 10,000$ for an imported vehicle. The producer can then sell this vehicle on the domestic market at the duty-inclusive price, making a profit of $\$ 3,000$. This profit amounts to a subsidy for exporters and equalises the returns from export markets with the returns from production for the domestic market.

The maximum subsidy provided by export facilitation is the rate of tariff on imported vehicles. The actual subsidy depends on how export credits accrue under the scheme. Export credits currently accrue on the basis of value added in exports. If the value added is 20 per cent, then the actual subsidy is 20 per cent times the rate of the tariff.

Following the introduction of export facilitation, production for the domestic market falls, exports increase and imports satisfy the residual domestic demand. But import prices faced by consumers do not fall. Consumers must effectively pay for both the subsidy given to producers supplying the domestic production and the subsidy given to exporters. 


\section{The Problem}

But that is not the end of the story. The discussion so far assumes that the total resources used in the automotive industry are fixed: that total production does not change in response to the introduction of export facilitation.

A well known effect of protection is that, when a tariff is introduced, the returns to the industry producing the protected good increase relative to the returns to other domestic industries. This means that total production in the protected industry increases at the expense of industries receiving less protection. In the same way, export facilitation increases the returns from exporting motor vehicles relative to the returns from exporting other goods or producing them for the domestic market. Indeed, the implicit subsidy available through the export facilitation scheme is considerably higher than assistance made available to other manufacturing industries. As a result, motor vehicle exports increase because production increases. So the size of the automotive industry increases at the expense of other domestic industries. Just as protecting domestic production is a net cost to the economy, so is subsidising exports.

\section{What It All Means}

All this means that we can never be sure that automotive exports actually lead to an increase in welfare. They are more likely to reduce it in exactly the same way that import protection does.

There are two additional problems. First, export facilitation creates a vested interest in continued tariff protection. To the extent that export facilitation provides a net subsidy to some activities, it creates a group of managers and workers whose interests depend on the continuation of export facilitation and subsequently on the maintenance of motor vehicle protection. This has led to pressures to oppose the government's plans to phase down the level of tariff protection given to the automotive industry.

Second, providing subsidies to exporters runs counter to Australia's usual position in multilateral trade negotiations. Australia has campaigned long and hard against the subsidies provided to US and European farmers. Yet Australia engages in what, in principle, is exactly the same sort of activity: taxing consumers to subsidise exporters.

David Pearce is Principal Policy Analyst at the Centre for International Economics, Canberra. 